\title{
Mining waste poisons river basin
}

Sir - The mining of polymetallic ores (tin, zinc, copper, lead, antimony, bismuth, silver, gold, cadmium, arsenic and so on) is the predominant industry of Bolivia. The mining districts of Potosí and Oruro (established in 1545) are located in the eastern margin of the central Andean plateau, the waters and streams of which converge in the great Pilcomayo river. The Bolivian sub-basin of the Pilcomayo covers an area of $98,100 \mathrm{~km}^{2}$.

The mining has produced huge quantities of waste materials, including the metals mined, along with mercury from the use of the amalgam method for extracting silver. (Between 1570 and 1900, the total discharge of mercury from silver mining in South America has been estimated at approximately 196,000 tonnes ${ }^{1}$.)

In November and December 1996, dead fish with symptoms of heavy metal poisoning, such as red eyes and soft flesh, were found floating in the Pilcomayo waters in western Chaco. These dead fish did not have mud in their gills; the Guaraní and Nivaclé population commonly eat fish which have been asphyxiated by silt. Elementary chemical analyses of the Pilcomayo waters display large amounts of lead, arsenic, mercury and other heavy metals. But the Paraguayan authorities, to protect their international agricultural and cattle exports, have chosen to ignore this pollution. At the same time, a mining dam retaining sulphide metal waste in Bolivia broke, spilling into the Pilcomayo. During the rainy season, the river overflows, changing the composition of the river water, but the heavy metals can be temporarily sealed in the mud deposits, producing possible future sources of poisoning.

The Chaco is a large tropical plain in the interior of South America, consisting of parts of Argentina, Paraguay and Bolivia $\left(840,000 \mathrm{~km}^{2}\right.$ in area). The sediments and material dissolved by the Pilcomayo river flow into the Paraguay river in Asunción, then into the Paraná river (in Corrientes), and the Paraná river finally carries them into the Plata river, in Buenos Aires.

The Guaraní and Nivaclé-Manjui population living in the huge alluvial fan of the Pilcomayo suffer from changes in the course of the river ${ }^{2}$, cholera epidemics (from drinking from polluted watercourses and pools $)^{3}$ and serious nutritional problems. Furthermore, they drink water directly from the river, and one of their main sources of food is freshwater fish such as Characidae, Pimelodidae, Loricariidae and Curimatidae ${ }^{4}$. The poisoning of the river Pilcomayo with heavy metals is a significant threat to the indigenous population. At the mouth of the Plata river, in Buenos Aires, the situation is better: purifying plants take the clay-rich waters of the river before human consumption, and the heavy metals from the Andean mines have, by this point, spread out into the massive additional flow of the Paraná and the Paraguay. But the poisoned waters of the Pilcomayo cross half the continent and affect millions of people in Argentina, Paraguay and Bolivia.

A few years ago, while carrying out a United Nations assignment in Bolivia ${ }^{5}$, we realized the huge economic difficulties faced by the Bolivian mining industry; all its resources are directed to establishing joint ventures with foreign companies for the sole purpose of obtaining injections of cash. The mining and environmental authorities do not appear to understand the problems that arise from dumping metallic sulphides in rivers.

This situation is too complex for the Bolivian government to solve on its own and should be looked into by those countries which mine, or have mined, in Bolivia, such as Spain, under the 'Mita' colonial system (before 1801) and Britain, Germany, Japan, Russia and the United States (after 1801) under different paracolonial regimes.

In short, the rich foreign countries that have been involved in the exploitation of Bolivia should take it upon themselves to analyse the pollution of the river Pilcomayo and the stability of the sulphide dumps if the authorities of Bolivia, Paraguay and Argentina continue to turn a blind eye to this complicated problem.

\section{Javier Garcia-Guinea}

Museo Nacional de Ciencias Naturales,

Dpto de Geologia,

C/ Jose Gutierrez Abascal 2,

28006 Madrid, Spain

e-mail:guinea@fresno.csic.es

\section{Maria Huascar}

Reserva Nacional Guaraní y Nivaclé del Pilcomayo, Departamento de Boquerón,

Mariscal Estigarribia, Paraguay

1. Nriagu, J. Nature 363, 589 (1993).

2. Iriondo, M. Geomorphology 7(4), 289-303 (1993).

3. Mazzafero, V. E. et al. J. Diarrh. Dis. Res. 13(2), 95-98 (1995).

4. Menni, R. C. et al. Hydrobiologia 245(3), 129-146 (1992).

5. Garcia-Guinea, J. Min. Ind. Int. 1026, 13-19 (1995).

\section{Explanation for singing}

\section{sands}

Sir - The studies by Goldsack et al. of 'singing' sands (Nature 386, 29; 1997), proposing that the grains have a silica-gel surface coating, seem to lead in a promising direction. I have long suspected that the source of the sounds, caused in some sands by dragging one's foot across the surface, is some kind of thin coating on the grains. The following observations led me to this notion.

For many years at Duneland Beach near Michigan City, Indiana, at the south end of Lake Michigan, I noticed that dry sands on the berm crest of the beach can generally be made to 'sing', whereas similar sands only metres away on the lower slope of the foredune behind the beach generally cannot. That suggests that the wind action

that sweeps the grains from the beach to the dune must alter them in some way.

That this alteration may be the abrasional removal of a surface coating is suggested by the observation that the beach sand develops a thin fragile crust when it dries out after storm overwash. This frail crust becomes evident above trapped airbubble holes along the upper part of the swash zone. After drying, the subsurface sand settles to a denser packing, leaving the crust to bridge over the resulting cavities. It may then collapse into what looks like Mars's chaotic terrain when one stamps on the nearby sand. Although Lake Michigan's water is fresh, it must contain sufficient salts to produce a coating on the grains that binds them together and makes them sing when disturbed - but a coating that is easily destroyed by wind abrasion when the grains are blown back into the foredune.

W. N. Melhorn (Purdue University) and
I planned to test this idea by asking S. V. Margolis (University of California, Davis) to look at the grain surfaces under the electron microscope. Margolis had studied other sand-grain surfaces, and we had samples of singing and non-singing sands from a number of sites. But he became preoccupied with another project, and then died of cancer before he could look at our sands.

That ended our study, but the work of Goldsack et al. suggests that we were on the right track, and they and others should look at the microtextures of the grain surfaces to see if they may indeed hold a key to the sands' acoustic properties.

Charles G. Higgins ${ }^{\star}$

Department of Geology,

University of California,

Davis, California 95616, USA

*Present address: PO Box 1727, Carmel Valley, California 93924, USA. 